Networking Knowledge: Journal of the MeCCSA Postgraduate Network, Vol. 4, No. 1 (2011)

\title{
ARTICLE
}

\section{'Tell me all about your new man': (Re)Constructing Masculinity in Contemporary Chick Texts}

\author{
AMY BURNS, Northumbria University
}

\section{ABSTRACT}

This article examines the representation of masculinity in contemporary 'chick' texts, with particular reference to The Holiday (2007). Chick texts encourage both female characters in the texts and the female audience to 'look at' and evaluate the male subject and they establish a specific formula of 'acceptable masculinity' for the hero, constructed of up to six facets: 'attractiveness', 'success',mystery, broken-heartedness, domesticity and being hopelessly devoted to the heroine. These facets suggest a utilising of Beynon's 'new man-ism' (2002) and imply that the archetypal 'new man' is what contemporary women 'want'.

\section{KEYWORDS}

Masculinity; Representation; 'New Man'; Chick lit; Chick flicks; 'The Holiday' 
Networking Knowledge: Journal of the MeCCSA Postgraduate Network, Vol. 4, No. 1 (2011)

\section{Introduction}

Implicit within the label 'chick' texts is that these are texts for and about women. Indeed, the chick culture 'phenomenon' of the 1990s "both reflected and promoted the new visibility of women in popular culture" (Ferriss and Young, 2008: 2) and caused an "important shift in women's popular texts" as they began to "examine women's experiences and desires" (Mabry, 2006: 192). The vast majority of work from the last decade on chick texts and the wider 'chick culture' has focussed primarily on the way these texts represent femininity, female agency or aspirations, and the interrelations between chick culture and postfeminism (Ferriss and Young (eds) 2006, 2008; Gill and Herdieckerhoff, 2006; Smith, 2008; Fest, 2009; Negra, 2009; Moseley and Read, 2002), but very little research has been done into how these texts represent masculinity or the male role.

Although these texts regularly explore female career aspirations (Gill and Herdieckerhoff, 2006), represent female consumers (Smith, 2008) or encourage female domesticity (Fest, 2009), most chick texts will "centre on a love plot" (Wells, 2006: 49) and "celebrate the pleasure' of heterosexual romance (Genz and Brabon, 2009: 76), which therefore means that male characters are an integral part of the narrative. ${ }^{i}$ Given that the vast majority of these narratives are told from the female point-of-view - through first-person narration in novels and "devices such as the voice over, the flashback and the fantasy sequence" in film or television (Mabry, 2006: 195) - these texts often use more space constructing and representing masculinity than they do femininity. Indeed, a chick text protagonist will usually identify, represent and discuss male characters at length, yet less often do they examine themselves as closely (with the exception perhaps of self-criticism and an overt emphasis on one particular issue, such as the character's weight). Since these are such popular texts, it is imperative to examine chick texts in order to establish how masculinity is constructed here, and to explore which masculinities and representations are favoured and used repeatedly. Many women regularly consume these texts so it is worth considering how ideologies about what men 'are' or 'should be' are being presented, and the potential social and political ramifications of this.

Aside from articles by Diane Negra (2008) and Laura Brunner (2010) and fleeting references 
Networking Knowledge: Journal of the MeCCSA Postgraduate Network, Vol. 4, No. 1 (2011)

in other recent studies on 'chick' genres (Ferriss and Young (eds) 2006, 2008; Gill and Herdieckerhoff, 2006; Harzewski, 2011), very little academic work exists analysing masculinity within chick texts. Therefore, this article seeks to contribute to this field by offering an initial analysis of representations of masculinity in contemporary chick texts. These texts are notably formulaic in construction (Mortimer, 2010; Harzewski, 2011), and usually conform to established conventions regarding characterisation; masculinity is no exception. I would suggest that certain aspects of masculinity are coded as superior to others in chick texts, so only a specific type of masculinity is acceptable for a chick text hero. Through textual analysis of a wide range of chick texts, but with specific reference to The Holiday (2007), I will examine the six facets of 'acceptable' masculinity embodied in the chick text hero and explore the persistence with which these features are portrayed. This will lead me to a broad discussion of how chick texts are constructing, or perhaps reconstructing, aspects of the 'new man' archetype from the 1980s.

It is appropriate to offer some parameters to my work regarding the texts I will examine, significantly, what constitutes a 'chick text' and where have they come from, and which chick texts will I focus on. Ferriss and Young explain that chick texts can be understood as a group of "American and British popular culture media forms focused primarily on twenty- to thirtysomething middle-class women" (Ferriss and Young, 2008: 1), and they go on to identify these forms to include films, literature, television, magazines, blogs, or music. The two 'forms' I examine are 'chick lit' (novels) and 'chick flicks' (films), having to exclude other types due to constraints of time and space. I would suggest that Ferriss and Young's outline also identifies the major demographic of consumers of these texts; obviously there will be exceptions, but for the most part the target audience of these texts are British and American women in their twenties and thirties.

Women's fictions have a rich heritage and many critics note that chick texts have inherited and developed elements and conventions from genres such as the 'woman's film', the 'novel of manners', the Harlequin or Mills and Boon romance novels and the 'sex comedy' (Harzewski, 2006, 2011; Wells, 2006; Mortimer, 2010; Abbott and Jermyn (eds) 2009). Yet chick lit in particular does appear to have a clear beginning, as it is described as a 'phenomenon' which "clearly does flow - albeit in numerous directions - from the original 
Networking Knowledge: Journal of the MeCCSA Postgraduate Network, Vol. 4, No. 1 (2011)

source of Bridget Jones" (Ferriss and Young, 2006: 5). Although given that Bridget Jones's Diary (Fielding, 1997) is a re-telling of Pride and Prejudice (Austen, 1813) and Bridget is often described as "a direct literary descendant" of Elizabeth Bennet (Ferriss and Young, 2006: 5), the lineage of contemporary chick texts to past genres is clear. Rosalind Gill claims that Bridget Jones's Diary "gave birth to the genre of chick lit" (Gill, 2007: 226), again establishing this as a foundational text and using a phrase which immediately genders the genre. Whilst chick flicks may not have such a precise beginning - the label is said to be "impossible to trace definitively" - they have been 'reclaimed' as part of the wider chick culture (Ferriss and Young, 2008: 2). Given that Bridget Jones' Diary is continually credited with "summoning the zeitgeist" of chick culture (Genz and Brabon, 2009: 76), I will use this text to define a historical boundary for my study: I will only examine texts published or produced since 1997.

\section{Here's Looking At You}

He is lovely. Love looking at Him asleep. V. sexy broad shoulders and hairy chest. Not that sex object or anything. Interested in brain. Mmmm... Must not obsess or fantasise... He looked gorgeous in his work suit.

(Fielding, 1999: 4, 5, 18)

As with the majority of chick texts, the male hero is readily on display in this extract from Bridget Jones: The Edge of Reason. Even though Bridget claims she is not objectifying her new boyfriend, she clearly is. The men in chick texts are there to be looked at by women, as part of a "new kind of representational practice" in popular culture where male bodies are depicted, "coded in ways that give permission for them to be looked at and desired" (Gill, Henwood and McLean, 2005: 38). This is in sharp contrast with "one of the most influential pieces of feminist writing... [which] has defined an entire field of study" (Edwards, 2006: 117), Laura Mulvey's seminal Visual Pleasure and Narrative Cinema, in which Mulvey claimed: "in a world ordered by sexual imbalance, pleasure in looking has been split between active/male and passive female. The determining male gaze projects... [women are] to be looked at and displayed" (Mulvey, 1975: 11). Clearly there has been a change which "disrupts conventional patterns of looking" (Gill, Henwood and McLean, 2005: 39), also identified by Yvonne Tasker in her work on the 'spectacular' body of 1980s action hero who "controls the 
Networking Knowledge: Journal of the MeCCSA Postgraduate Network, Vol. 4, No. 1 (2011)

action" whilst also being "offered up to the audience as a sexual spectacle" (Tasker, 1993: 16). There is now a perceptible representation of the female gaze in popular culture.

Yet what is significant about chick texts, as Laura Brunner explains with regard to the popular chick television series Sex and the City, is that now women are not only looking at men, they can also evaluate them:

[Men] are presented as objects for consumption for both the characters and the female audience... Part of the innovation of Sex and the City is that playgirls are now commodifying and evaluating men in the same way that men have always judged women... The show contests cinematic and television convention, reversing the usual trend of the male subject as the consumer of the female object of desire.

(Brunner, 2010: 87-88)

I would suggest this is not just the case for Sex and the City, but that this ground-breaking series paved the way for all chick texts. Crucially, there is a two-fold representation of men to both the women within the text (the characters) and the women outside of the text (the audience). These two groups are both invited to 'evaluate' the male subject, but furthermore, I propose that the female audience can also evaluate the female character's evaluation of the male subject because of the formulaic conventions of these texts and the ideology of acceptable masculinity which I will go on to discuss. I will return to this idea later.

One text that demonstrates a representation of men to both the female characters and the female audience is the chick flick The Holiday, through its portrayal of Graham (Jude Law). Significantly, in his first scene of the film Graham is shown entering a pub looking for friends and then joining them for a drink, all the while being watched not only by the audience but by a woman in the pub. At no point in this scene does he speak. Later in the film Graham returns to this pub where the heroine Amanda (Cameron Diaz) is waiting for him; she sees him first and is shown watching him while he is looking for her but no words are exchanged. Soon after Amanda watches Graham as he drives, meaning he of course is unable to look back at her for any length of time. Also, the film uses fantasy sequences to explore what Amanda is thinking, and here Graham is seen through her eyes but again does not speak. Quite clearly this man is 'to be looked at'. Furthermore, that he is silenced limits the agency of the 
Networking Knowledge: Journal of the MeCCSA Postgraduate Network, Vol. 4, No. 1 (2011)

character; he (like Mark Darcy in the earlier quote) has been objectified and can now be evaluated. Which leads to a significant question: in what ways is masculinity evaluated in chick texts?

I propose that acceptable masculinity of a chick text hero is comprised of six facets, and a male character must conform to at least three in order to qualify as a hero. Yet many heroes will demonstrate more than three, including the aforementioned Graham from The Holiday who exhibits all six; I will therefore use Graham as a starting point for discussion of each of these attributes. Interestingly, The Holiday is a film with two romance narratives and consequently two hero/heroine pairings; the other is Miles (Jack Black) and Graham's sister Iris (Kate Winslet). Miles conforms to three of the traits as a hero should, but Graham is worth discussing in depth because of his overwhelming adherence to all six features.

\section{'What a Handsome Fine Looking Gentleman He Is'}

He's not unattractive. Not by any means. In fact he's.... oh, God... he's stunning. Scarily handsome. He has dark blond hair, penetrating blue eyes and... a physique that would make anyone go weak at the knees: tall and toned, broad-shouldered, with just the right amount of muscle... he's very good-looking.

(Costello, 2009: 23-24, emphasis in original)

A chick text hero is usually considered 'attractive'. In The Holiday Amanda says Graham is "insanely good-looking" and a brief perusal of the internet confirms that there are many other women in agreement with this statement regarding Jude Law. ${ }^{\text {ii }}$ However, there are other techniques at work in chick flicks to construct and confirm 'attractive' masculinity. As I have already noted, Graham is depicted being looked at by a number of different women which implies that he is worth looking at, an 'object of desire'. Similarly, Andrew (Ryan Reynolds) in The Proposal (2009) is watched by various women as he runs to work and also given the phone number of his female coffee barista, and Ben (Matthew McConaughey) in How to Lose a Guy in Ten Days (2003) is watched by a number of women as he enters his office. It seems reasonable to suggest that these men are 'attractive', given their appeal to so many women. However, there is a further technique used to suggest 'attractiveness' in these chick flicks and many more: displaying the uncovered male body. 
Networking Knowledge: Journal of the MeCCSA Postgraduate Network, Vol. 4, No. 1 (2011)

Gill et al suggest that "a significant change has occurred, in which men's bodies as bodies have gone from near invisibility to hypervisibility" (Gill, Henwood and McLean, 2005: 39, emphasis in original), and this is certainly true of chick flicks. Graham's topless body is shown during a bedroom scene of The Holiday, yet his female co-star's body remains covered; the same thing occurs in Music and Lyrics (2007), He's Just Not That Into You (2009) and Valentine's Day (2010). Men are regularly shown changing their shirt or showering in chick flicks, a process which often allows for a lingering short of the male torso. This happens most notably in Sweet Home Alabama (2002), A Lot Like Love (2005) Just Like Heaven (2006) and How to Lose a Guy in Ten Days. Significantly, in each of these scenes the male character is also being watched by one or more female characters, even though in the case of A Lot Like Love where the female character is also changing her clothes, her body is not shown. There is a further scene in A Lot Like Love worth discussion. The heroine Emily (Amanda Peet) is a photographer, and she and Oliver (Ashton Kutcher) pose together for a nude photograph. However, whilst they hide behind a car and undress at the same time, Oliver must stand alone on a rock as Emily sets up the camera shot; she is not only watching him but critiquing him from a professional perspective. Ashton Kutcher's body is fully on display, lit by a full moon and the car headlights, yet Emily remains in shadow as she scrutinises him for the photograph, emphasising that the male body is not only observed but evaluated.

Perhaps the most extreme example of the difference between the way female and male bodies are portrayed in chick flicks is in The Proposal. Both Ryan Reynolds' and Sandra Bullock's bodies are on display during a scene where the characters go to take a shower without realising the other is there. Yet Bullock's body becomes the tool for physical comedy, even slapstick comedy with a small dog, whilst Reynolds simply strips off. Even when they literally bump into each other fully naked, as Bullock's character scrambles to hide behind furniture and cover herself up, Reynolds' body remains on view as he calmly ties a towel around his waist.

The most prominent occurrence of male nudity is in the first film version of Sex and the City (2008) and unsurprisingly it is Samantha (Kim Cattrall) who is 'looking'. Not only is Samantha regularly shown watching her live-in boyfriend Smith (Jason Lewis) walk around 
Networking Knowledge: Journal of the MeCCSA Postgraduate Network, Vol. 4, No. 1 (2011)

topless, she also spies on her fully naked next-door neighbour whilst he engages in various sexual encounters and, ultimately, when he is in the shower. Interestingly, during the film, as in the television series, Samantha is often situated in traditionally masculine roles: she runs her own business, she gives a wedding speech, she controls Smith's career and at one point she smokes a cigar, accompanied by three men. Perhaps the reason Samantha is given so many opportunities to 'look' is because she has earned her place in this traditionally male role, and through Samantha the (probably mostly female) audience is given the chance to 'look' vicariously with her and share her 'visual pleasure'.

'Attractive' masculinity in chick flicks is inextricably linked with the male body itself (see Bordo 2001, 2003 for wider discussion of the male body in film). The body is regularly displayed and notably 'looked at' - which implies that it is worth looking at - and this confirms 'attractiveness' to the audience. A similar idea is at work in chick lit: if a male character's appearance is worth overt positive description, it would follow that they are considered 'attractive'. However, it is usually far simpler to identify 'attractive' masculinity in chick lit, as characters are usually outright described as such: "I look up at him. You're so gorgeous, I think." (Burgess, 2011: 359) "there's Luke, looking all tall and gorgeous" (Kinsella, 2001: 49); "dark hair... as always, he looked gorgeous" (Jones, 1997: 183). This is just a small selection of the multitude of references to the 'gorgeous' heroes of contemporary chick lit (see Fielding, Costello, Nathan and Toon for further uses of 'gorgeous'). Similar language is used again and again and it would seem that it is the classic adage of 'tall, dark and handsome' which appeals most of all: "very tall... the sort of tall that makes you always feel protected and safe" (Green, 2005: 19); "a jolt goes through me as a tall, dark [man]... stands up and smiles at me" (Toon, 2007: 48); “he's very tall... dark and handsome... He's very attractive" (Bagshawe, 2004: 5); "he’s absurdly handsome... his hair is dark" (Costello, 2011: 7). Without the visual medium of chick flicks, chick lit has instated (or perhaps reinstated) a shorthand for 'attractive' masculinity. Once again this indicates a nod to Jane Austen and Pride and Prejudice as Mr Darcy is first introduced as a "fine, tall person" with "handsome features" (Austen, 2006: 10).

So first and foremost the heroes of contemporary chick texts are 'attractive', 'gorgeous' men with bodies worth looking at. I would suggest that the vast majority of heroes conform to this 
Networking Knowledge: Journal of the MeCCSA Postgraduate Network, Vol. 4, No. 1 (2011)

first facet of acceptable masculinity, although there are occasional texts which do not overtly emphasise this feature, for example Alexandra Potter's novels Calling Romeo (2011) and Me and Mr Darcy (2007), and the films Wimbledon (2004) and The Holiday (the second narrative featuring Miles and Iris). Yet these are texts where the true 'hero' has had to win the heroine from an 'anti-hero' who is perhaps far better looking, but not the right match for the heroine because he does not love her or understand her as the true hero does; therefore 'attractiveness' pales to insignificance. I will return to this idea in my discussion of the final attribute.

\section{Measures of Success}

Everyone talks all the time about what a genius he is... He started Brandon Communications from nothing, and now it's the biggest financial PR company in London... he was listed in some newspaper as one of the cleverest entrepreneurs of his generation. It said his IQ was phenomenally high.

(Kinsella, 2000: 24)

Ideal masculinity in chick texts is almost always represented as 'successful'. Whilst the hero's career can be almost anything from business to politics to media to sport and beyond, more often than not he will be at the top of his field. Indeed, the idea of being at the 'top' is especially significant in Bridget Jones's Diary. In the novel Mark Darcy is described as a "top-notch lawyer" with "masses of money" (Fielding, 1997: 9), and then in the film (2004) Bridget (Renee Zellweger) introduces him as a 'top' barrister, a phrase he then repeats in a slightly teasing way, showing an initial connection between the two characters. Of course, Mark Darcy was based on Mr Darcy who was well-known as "having ten thousand a year" (Austen, 2006: 10), which is perhaps the Regency equivalent of 'top-notch'.

Chick texts most notably establish their heroes as 'successful' with regards to their career. Men in chick texts rarely just 'work' - they either own the company or they are the best at what they do. In chick lit they are 'high-flying' journalists (Potter, 2009: 14), Grand Prix winning Formula One drivers (Toon, 2009), Oscar-winning actors and directors (Nathan, 2000; Bagshawe, 2004), rock stars (Kelk, 2009; Toon, 2008), or men who are simply "top of the class at everything" (Costello, 2010: 76). In chick flicks they are successful executives (How to Lose a Guy in Ten Days; The Family Stone, 2005), lawyers (Letters to Juliet, 2010; 
Networking Knowledge: Journal of the MeCCSA Postgraduate Network, Vol. 4, No. 1 (2011)

Bridget Jones's Diary), chefs (The Devil Wears Prada, 2006; No Reservations, 2007) politicians (Maid in Manhattan, 2003; Love Actually, 2003), journalists (The Runaway Bride, 1999; 27 Dresses, 2008) or even Wimbledon-winning tennis players (Wimbledon). With all of these examples, career 'success' implies financial 'success' and in many cases signifiers of wealth are prominently displayed in the form of cars, clothing, houses and gadgets. Significantly though, especially with regard to Graham in The Holiday, sometimes the signifiers of wealth are used to imply career success, even when it has not been explicitly labelled. Graham is a book editor, but no details are given as to any particular 'success', yet he drives an expensive Range Rover and lives in a very large farmhouse in Surrey: both would certainly imply financial accomplishment. The same is true of Miles in the same film; whilst his 'success' is not explicitly stated, he drives a flashy sports car and is shown working from home as a composer with an extensive range of high-end specialist technical equipment.

A further signifier of wealth used in many films - and notably by Graham in his first scene of The Holiday - is the wearing of a suit. Tim Edwards explains that "dress acts as a code or performs a signifying function" (Edwards, 1997: 26), and he has examined the wearing of the suit in depth, concluding:

The suit still maketh the man most completely. It remains a potent symbol of success... it retains an essential continuity, almost tranquillity of form and meaning amongst the postmodern confusion of contemporary fashion, standing for social tradition and successful... masculinity.

(Edwards, 1997: 22)

He also suggests that it has an association with 'intense sexuality' and 'eroticism' (Edwards, 1997: 20, 21), connecting the suit with both success and attractiveness. Brunner explains that in Sex and the City, "Big's suit is a symbol of his masculinity" (Brunner, 2010: 93). I would certainly agree with this, but would also contend that it is a symbol of successful masculinity, both successful in the sense of a man with a good career, and in the sense of a man having achieved acceptable masculinity.

The suit is used regularly in chick flicks to construct a representation of 'successful' masculinity, particularly in a film's opening scenes when identity is being established. The 
Networking Knowledge: Journal of the MeCCSA Postgraduate Network, Vol. 4, No. 1 (2011)

Proposal, Definitely Maybe (2008), The Family Stone, You've Got Mail (1999) and The Wedding Date (2005) all utilise the suit as a signifier of 'success', but perhaps the most extreme use is in Two Weeks Notice (2002). In this film, George (Hugh Grant), a billionaire real estate magnate, wears a suit in almost every scene. Significantly, in the first of the few scenes when he is not wearing a suit, he stands in his closet in the process of choosing one to put on and literally hundreds of suits are hung on racks around him; an overt display of excess to emphasise George's 'success'.

Whilst career 'success' and the suit are important factors in constructing acceptable masculinity, and often used in chick texts, they are not imperative. Firstly, 'success' must be balanced correctly with the attributes I will go on to discuss, lest acceptable masculinity become swallowed up in 'success'. When Meg Ryan and Tom Hanks' characters are arguing in You've Got Mail, prior to them forging a relationship, the final blow she attacks him with is to say "you're nothing but a suit". Clearly, if masculinity is reduced to only success it is not acceptable within chick texts, even if it is coupled with 'attractiveness'; hence my assertion that an acceptable hero must embody at least three of the six attributes. 'Success' is important, but masculinity cannot be reduced to just that.

Furthermore, in some chick texts the emphasis is on creative skill rather than career and/or financial 'success': Nathaniel in The Undomestic Goddess (Kinsella, 2005) is a highly skilled gardener, Nick in Mr Maybe (Green, 1999) is a writer, Ed in Fairytale of New York (Dickinson, 2009) is a florist, Matt (Mark Ruffalo) in 13 Going on 30 (2004) is a photographer, Jake (Josh Lucas) in Sweet Home Alabama is a glass blower, and Jack (Ashton Kutcher) in What Happens in Vegas (2008) is a carpenter. Clearly, being 'successful' can also be appropriated in this way. Interestingly, book editor Graham in The Holiday combines both career 'success' and creative skill, and some of the creatively skilled heroes mentioned above are also able to use their skill to achieve career and/or financial 'success': Nathaniel owns his own business, Nick gets a publishing deal and Jake's glass is revealed to sell for high prices. It is this idea of a 'revelation' which underlies the third facet of acceptable masculinity.

\section{Man of Mystery}


Networking Knowledge: Journal of the MeCCSA Postgraduate Network, Vol. 4, No. 1 (2011)

"I think it's safe to say there was no affair... [the] real secret was that Josh is in fact a generous, trustworthy type, taking responsibility for his father's actions... it means he's a hell of a lot nicer than you thought."

(Nathan, 2003: 517)

The idea of a man of mystery who is later revealed to be the hero, usually when the heroine discovers something about his home, work or personal life, is certainly not new and once again demonstrates how chick texts are emulating Pride and Prejudice. Elizabeth Bennet responds to her sister's question about how long she has loved Mr Darcy by explaining: "I believe I must date it from my first seeing his beautiful grounds at Pemberley" (Austen, 2006: 362). It is only when Lizzie visits him at home, meets his sister and his staff, and learns of his true nature that she begins to fall in love with him. Proving once again that "chick lit's heroines are the direct descendents of Austen's" (Wells, 2006: 59), it is unsurprising to see the mysterious, proud Mr Darcy replicated in the chick's counterpart, the man of mystery.

The Holiday's Graham is a man of mystery to Amanda until she visits his home. Until then she knows only surface details of his life, and the most significant thing - that he is a widower with two young daughters - is hidden. In some ways, Graham is an anomalous 'man of mystery' in that Amanda clearly likes him prior to the revelation; usually, as with Mr Darcy, 'men of mystery' are disliked by the chick heroine until the revelation occurs.

Josh from The Nanny, referenced in the opening quote of this section, is described by the heroine as "so immature... a rude, arrogant bastard" and she says outright "you disgust me" (Nathan, 2003: 246, 431). Another of Nathan's heroes, Harry, is described as a "supremely arrogant bastard" (Nathan, 2000: 118); Jimi in Do You Come Here Often? is "all proud, and arrogant, and cocksure" (Potter, 2009: 209) and Alekos in Out Of The Blue has a "Greek-god complex...and an ego to match" (Jones, 2008: 29-30). In a similar way the heroes of 27 Dresses and Just Like Heaven are described in turn as a 'creepy cynic' and a 'filthy pig' by their respective heroines. Yet with all of these examples it is these men whom the heroines will have fallen in love with by the end of the text, their previous behaviour and attitudes forgotten or explained away.

What is significant about the 'man of mystery' with respect to establishing masculinity is the 
Networking Knowledge: Journal of the MeCCSA Postgraduate Network, Vol. 4, No. 1 (2011)

power that comes from being such a man. The heroines become fixated by these men, even to the point of obsession. They may try to convince themselves and others that these men are insignificant or that they hate them, but they are unable to stop thinking about them. Jo in The Nanny thinks about Josh even whilst she is having sex with another man: "It was nice, but she'd have preferred it if she hadn't been listening out for the door with one ear... and thinking about Josh with the rest of her body" (Nathan, 2003: 222). Michael Kimmel explains that "masculinity is measured by power" and that "manhood is equated with power - over women" (Kimmel, 1994: 125, 136), and Lynne Segal suggests the same: "[masculinity] exists in the various forms of power men ideally possess: the power to assert control over women" (Segal, 2007: 104). In these 'man of mystery' texts the hero knowingly or unknowingly holds the power within the relationship by asserting control over the heroine. Given that "much of what we associate with masculinity hinges on a man's capacity to exercise power and control" (Kaufman, 1994: 142), the 'man of mystery' establishes itself as an acceptable form of masculinity.

The man of mystery abounds in chick texts, to a greater extent than I have identified here, because often the reason for the mystery is the fourth aspect of masculinity, which I will now discuss.

\section{How can you mend a Broken Heart?}

"Oh, I get it."

"No, you don't. You don't know what I'm going to say."

"I can guess. You broke her heart right, and now Oscar can’t forgive you for doing it?"

"No, the other way around actually, she broke mine."

"Oh." I felt guilty for judging him. "Oh right. I'm sorry."

(McNamara, 2010: 100)

Mark Rubinfeld has identified four types of Hollywood love story used in romantic comedies. One of these is the 'redemption plot' - the "most frequently utilised" of the four - which can take two forms: 'cold-hearted redemption' and 'broken-hearted redemption' (Rubinfeld, 2001: 13). He goes on to explain that the broken-hearted hero is: "more loveless than heartless; his wounds stem from loneliness... he is aware that something is missing" (Rubinfeld, 2001: 27). 
Networking Knowledge: Journal of the MeCCSA Postgraduate Network, Vol. 4, No. 1 (2011)

In agreement with Rubinfeld, I have found the broken-hearted hero to be a regular feature of chick texts. He is broken-hearted because a previous partner - either girlfriend, fiancée or wife - has left him, through choice or through death.

Graham in The Holiday is clearly broken-hearted. When Amanda realises he has children but no wife she asks if he is divorced, spelling the word as the children are listening. In reply he spells 'widower', yet is unable to even look up as he does. When they talk later he admits to Amanda: "I'm afraid of what another person might do to who we are and how we get from one day to the next". Graham is not the only widower in chick texts, he is accompanied by the heroes of Just Like Heaven, New In Town (2009) and Failure to Launch (2006) - although in this final text Matthew McConaughey's character was engaged when his partner died, not married, but he is clearly broken-hearted and unable to move on with his life. There are also fictional widowers in chick lit: Mark in The Learning Curve (Nathan, 2006), and Ryan in The Nearly-Weds (Costello, 2009).

Broken-hearted heroes may be such because they were spurned when a wife/girlfriend left them, often for another relationship. There is a large collection of these: the original example of Mark Darcy in Bridget Jones's Diary has since been emulated with Toby in 31 Dream Street (Jewell, 2007), Jude in Twelve Days of Christmas (Ashley, 2010), Sean in From Notting Hill With Love... Actually (McNamara, 2010), Jimi in Do You Come Here Often? and Robert in A Girl Like You (Burgess, 2011), as well as the heroes of 27 Dresses, Love Actually, Notting Hill (1999) and Miles in The Holiday. All of these broken-hearted heroes are capable of loving greatly - they have proven so by their past - but need to be restored by the heroine.

There is a complication to the 'broken-hearted redemption plot' when it is the heroine herself who knowingly or unknowingly has been the one to break the hero's heart. This is the case in the novels Remember Me? (Kinsella, 2008) and Persuading Annie (Nathan, 2001), and the chick flicks 13 Going on 30 and Sweet Home Alabama. Yet even here, the "healing heroine" is able to make up for her past mistakes, and the outcome is, as always, "what most uncoupled people... seek: a Hollywood... happy ending” (Rubinfeld, 2001: 27).

Perhaps the most broken-hearted hero of all is Notting Hill's Will Thacker (Hugh Grant). Not 
Networking Knowledge: Journal of the MeCCSA Postgraduate Network, Vol. 4, No. 1 (2011)

only does he begin the film with a broken heart - his wife left him "for a man who looked exactly like Harrison Ford" - but he then proceeds to have his heart broken twice by the heroine, film star Anna Scott (Julia Roberts). Will's heartbreak is emphasised heavily by the film's soundtrack; after the first time Anna leaves, a montage of a morose Will is shown over the song 'How Can You Mend A Broken Heart?" by Al Green. When Anna leaves Will the second time another montage is used, set against "Ain't No Sunshine" by Bill Withers. Given that a film's soundtrack can be a 'contextualising strategy' which works to support a film's 'narrative force' (Rüll, 2008: 82), Notting Hill works hard to ensure the audience is aware of Will's heartbreak.

Rubinfeld suggests that the broken-hearted redemption plot serves a "commercial and ideological function": "to emotionally appeal to females by emphasising the female's emotional appeal" (Rubinfeld, 2001: 13, emphasis added). However I would contest that this is not the case with chick texts. I propose that the broken-hearted hero emotionally appeals to females, both characters in the text and the audience, by emphasising the male's emotional capability. These men love; they have loved before and, with the heroine's help, they will love again. Masculinity here is being represented as emotionally expressive and loving - traits associated with the archetypal 'new man' of the 1980s (Hondagneu-Sotelo and Messner, 1994; Chapman, 1988; Mort, 1996; Beynon, 2002). This aspect of the 'new man' image is clearly acceptable for a chick text hero, and the following facet can also be associated with this archetype, further reinforcing the chick text hero's assimilation of the 1980s 'new man'.

\section{Father Figure / Domestic God}

This morning Dan got Tom up for breakfast, gave him his bottle, fed him his Weetabix while he read aloud to him from the Guardian in a sing-song childlike voice... Dan is sitting in the rocker, reading Guess How Much I Love You to Tom. (Green, 2005: 200, 328)

The nurturant, committed father and/or culinary-skilled 'domestic god' is thriving in chick texts. In The Holiday Graham outlines his domestic accomplishments as a single father: "I'm a full-time dad, I'm a working parent... I'm a guy who reads parenting books and cookbooks before I go to sleep... I'm learning to sew!" There are other single fathers in chick texts; in the 
Networking Knowledge: Journal of the MeCCSA Postgraduate Network, Vol. 4, No. 1 (2011)

novels The Learning Curve and The Nearly-Weds, and in the films Definitely Maybe, New In Town and Enchanted (2007) ${ }^{\text {iii }}$. There are also 'father figures': men who are not biological fathers, but care for children nonetheless, seen in the films Failure to Launch, No Reservations, What Happens in Vegas and You've Got Mail, and also in the novel Can You Keep A Secret? (Kinsella, 2003). Furthermore, many chick lit heroes express their desire to be a father and openly talk about wanting to have children: "I want tons of [kids]... I wouldn't mind supporting a family" (Bagshawe, 2005: 200); "I've always wanted children" (Jones, 1997: 190); "I've waited for this child for years" (Green, 2002: 227).

Alongside the representation of masculinity as an involved father-figure is an increasingly recognisable image of the 'domestic god'. Much has been written in the last decade on the idealisation of domesticity in the postfeminist period (Hollows, 2006; Gillis and Hollows, 2009; Fest, 2009; Negra, 2009), yet this research focuses on femininity and domesticity and the 'domestic goddess' figure. I would suggest that in chick texts at least, there is a level of masculine domesticity on display, which is in stark contrast to the traditional distinction "between home and work, between domestic and public [that] has always been read in gendered terms" (Fest, 2009: 49). In chick texts men are often happy to be found in domestic spaces, fulfilling domestic roles: "Mark had donned a specially bought apron with a picture of Father Christmas on it... as he dutifully cooked the turkey" (Nathan, 2006: 268); "Sean quickly took charge and the kitchen was soon filled with countless delicious aromas" (McNamara, 2010: 333); "Henry... does more than his fair share of the cleaning" (Costello, 2010: 8).

The hero of Babyville (Green, 2002), Mark, fulfils both the more traditional image of 'public' masculinity - he is a successful and very well-paid lawyer - and the role of 'domestic god'. He owns a six-bedroom house in London and describes himself as "someone who loves being at home" (Green, 2002: 243). He loves to cook - "there's only one thing I enjoy more than a bloody good litigation, and that's slaving over a hot stove" - and claims to be "God's gift to ironing" (Green, 2002: 240, 244). Having spent a day with him, his new girlfriend says she feels "so nurtured" (Green, 2002: 247).

Even two of the most well-known chick text heroes are happy to be found in the kitchen, 
Networking Knowledge: Journal of the MeCCSA Postgraduate Network, Vol. 4, No. 1 (2011)

usually even more so than their respective heroines: Mark Darcy and Mr Big (Chris Noth). When Bridget attempts to cook herself a birthday dinner, it is only saved by Mark stepping in to help, and in the first Sex and the City film, Mr Big is shown cooking for Carrie (Sarah Jessica Parker), who readily admits that she herself never cooks: "I use my oven for storage". iv Both of these men seem happy in the traditionally feminine domestic space, although this does lead to further questions regarding Bridget/Carrie and their femininity that space does not allow me to address in this context.

As with the emotionally expressive broken-hearted hero, the father figure/'domestic god' of chick texts owes more than a little to the 'new man' of the 1980s. I will return to this after discussion of the sixth and final facet of acceptable masculinity - and where the previous aspects might be optional, this final one is entirely non-negotiable for all heroes.

\title{
Hopelessly Devoted
}

\begin{abstract}
Alex was the one... for the last two months he had been the most attentive, thoughtful, heartbreakingly wonderful boyfriend I could ever have imagined. He bought me little gifts... he surprised me with indoor picnics when I was on deadline, ran out to pick up breakfast before I woke up... Alex was competing for the title of world's best boyfriend.

(Kelk, 2010a: 3-4)
\end{abstract}

Perhaps the most important facet of all when it comes to acceptable masculinity for a chick hero is that he is completely and utterly in love with the heroine - if not at the beginning of the text, certainly by the end. To refer for the final time to Graham in The Holiday, he is clear about his feelings for Amanda: "I am in love with you. I apologise for the blunt delivery, but as problematic as this fact may be, I'm in love with you.... I can't figure out the mathematics of this, I just know I love you". Declarations of love are common in chick texts and are usually found toward the end of the narrative: "Becky's instincts match no-one else's... she makes me laugh. She makes me enjoy life. And I love her more than anything else in the world" (Kinsella, 2007: 343); "I've loved you from the first moment we met and I haven't stopped loving you every day since" (Dickinson, 2009: 384); "I love the way you take everything and nothing seriously... I love that your brain is always working on three things at once... I love the way you arrange the cutlery... I love you" (Burgess, 2011: 410-411). 
Networking Knowledge: Journal of the MeCCSA Postgraduate Network, Vol. 4, No. 1 (2011)

Even in texts where the couple have bickered, argued or seemingly hated each other throughout, by the end the hero will be devoted to his heroine, for example in the novels Girl on the Run (Costello, 2011), Chasing Daisy (Toon, 2009) and Monday's Child (Bagshawe, 2004) or the chick flicks You've Got Mail, Two Weeks Notice, Just Like Heaven, How to Lose a Guy in Ten Days or He's Just Not That Into You. This may be because, as with the heroes of traditional romance novels studied by Tania Modleski, "the hero's expressions of hostility and derision... [are because of] his inability to admit, even to himself, how much [the heroine] inflames his passion and rouses his admiration", and perhaps, "all the while he is being so hateful, he is internally grovelling, grovelling, grovelling” (Modleski, 1982: 41, 45).

This final facet also ensures the heroine is matched with the correct man, rather than a man who may potentially appear to be the right one but is in fact just a 'foil' (Rubinfeld, 2001: 33). A foil is often utilised in chick texts to create the issue of a 'love triangle', which I mentioned briefly in the discussion of 'attractiveness'. Significantly, it is this final aspect of masculinity - of a true hero being hopelessly devoted to the heroine - which will always give away a foil. For example in 27 Dresses, Jane (Katherine Heigl) believes she is in love with her boss, George (Edward Burns), whilst Kevin (James Marsden) is in love with her. Towards the end of the film Kevin says to Jane "I think you deserve more than what you've settled for... I think you deserve to be taken care of for a change", which is in sharp contrast to George saying to her "I can always count on you. You never say no, which I love." At this it becomes clear to Jane which is the right man for her: the one who wants the best for her and wants to give her more, not the one who uses her. A foil might appear to measure up to being a hero, he may even adhere to any or all of the other five aspects of masculinity, yet if he does not wholeheartedly love the heroine, if he is not hopelessly and utterly devoted to her and want the best for her, he can never be a hero.

\section{Chick Text Shorthand}

I spot the blurry outline of one of the fathers from school walking down the road towards us. He is talking on his mobile phone and running his fingers through his thick dark hair... it's Sexy Domesticated Dad.

(Neill, 2008: 13) 
Networking Knowledge: Journal of the MeCCSA Postgraduate Network, Vol. 4, No. 1 (2011)

Whilst this novel, The Secret Diary of a Slummy Mummy, is an example of the new sub-genre of chick lit, 'mummy-lit', ${ }^{v}$ this text nonetheless offers an interesting insight into how acceptable masculinity has come to be understood in these genres. This character, known simply as 'Sexy Domesticated Dad' is the ultimate man of mystery. Very little is known of him beyond this label; it is half way through the novel before the reader is even given his real name. 'Sexy Domesticated Dad' is not the hero of the novel, as this is 'mummy-lit' the heroine is already in a committed relationship with her 'hero' (the father of her children), but the use of this shorthand implies an understanding between the creators of chick texts and the audience who will consume them.

Furthermore, given the overwhelming consistency of these six aspects of masculinity, any regular consumer of these texts will surely become familiar with the formula of a chick text hero fairly quickly. Here I return to Brunner's claim that both the female characters and the female audience are involved in evaluating masculinity in these texts (Brunner, 2010). As I previously stated, not only can the female audience evaluate the male subject, but they can evaluate the female characters' evaluation of the male subject, because they are able to recognise this formula. Once again this connects with Modleski's work on traditional romance novels:

It is easy to assume... a large degree of identification between reader and protagonist, but the matter is not so simple. Since the reader knows the formula, she is superior in wisdom to the heroine and thus detached from her.

(Modleski, 1982: 41)

The reader (or audience member) may feel emotionally attached to the heroine, but there remains a sense of distance because of the innate knowledge the chick text consumer has of chick heroes. It could therefore be suggested that part of the consumer's pleasure of enjoying these texts comes from this superiority, but further research would be needed to fully explore this.

Having established how chick text heroes are constructed from these six facets of acceptable masculinity it is worth considering not only where else these features have been previously 
Networking Knowledge: Journal of the MeCCSA Postgraduate Network, Vol. 4, No. 1 (2011)

used, notably in the image of the archetypal 'new man', but what this may mean for the women consuming these texts.

\section{The New 'New Man'}

"You can tell me all about your new man. You've been very secretive about him." (Costello, 2010: 299)

In the early 1980s, a cultural 'phenomenon' exploded into contemporary representational spaces: the image of the 'new man' (for the 'new man' as a phenomenon see Nixon, 2001 and Mort, 1996). For most of that decade, the 'new man' enjoyed hegemonic status as a highly visible icon and in 1988 Rowena Chapman noted, "Child of our time, the new man is all about us" (Chapman, 1988: 225). Critics identified the 'new man' as a "college-educated professional... a highly involved and nurturing father, 'in touch with' and expressive of his feelings, and egalitarian in his dealings with women" (Hondagneu-Sotelo and Messner, 1994: 202); he is "suffused with emotion and warmth... caring, vulnerable, and yet playful... competent... centred and ordered" (Chapman, 1988, 245); he is "highly invested in his physical appearance" and, significantly, he encompasses "many of the traits previously thought of as feminine" (Gill, 2003: 37, 42).

John Beynon has discussed the 'new man' more recently and identifies two categories within this cultural icon: 'new man-as-narcissist' and 'new man-as-nurturer' (Beynon, 2002). The 'new man-as nurturer' is clearly identifiable in chick texts, confounded by the attributes of father figure and domestic god, and also to some extent the intertwined man of mystery and broken-hearted hero, as these attributes work to emphasise the hero's emotional capacity. It is perhaps harder to readily recognise the 'new man-as-narcissist' because of the dominance of 'new man-as-nurturer', but the narcissist is there within the emphasis on 'attractiveness' and the physical male body and masculine 'success' and achievement. Beynon goes on to discuss how these two 'strands' of the 'new man' have now developed:

It is my contention that these two hereditary (in some ways antithetical) strands have been woven together in the public mind into a pot-pourri, nebulous new man-ism...The present-day young have all been touched by this new man-ism in 
Networking Knowledge: Journal of the MeCCSA Postgraduate Network, Vol. 4, No. 1 (2011)

one form or another... new man-ism remains a highly pervasive and masculine 'message', one that bombards men in various forms.

(Beynon, 2002: 120)

The new man-ism that Beynon is referring to is certainly alive and well in contemporary chick texts, which suggests that this message is not only bombarding men, but women too.

\section{Conclusion: What Women Want?}

New Man is an expression of the repressed body of masculinity. It is a fraught and uneven attempt to express masculine emotional and sexual life... similarly the changing face of fatherhood is full of inconsistencies and contradictions... the new liberalised image of men... has been taken up and encouraged in the media... it looks nice and it's what women want.

(Rutherford, 1988: 32, 34, emphasis added)

Obviously without further research actually asking women about the 'new man' image of masculinity reconstructed in the chick text hero it it impossible to say absolutely that this is what women want. Yet two facts remain. Despite their formulaic approach these are consistently popular texts read by many contemporary women and their popularity shows little sign of dwindling, which could indicate that this version of masculinity is indeed what women want. Secondly, through this formulaic construction and repeated representation of this particular ideology of masculinity, perhaps women feel they want this because they are told by these popular cultural texts that they should want this.

Significantly though, critics claim that the 'new man' "never became a fixture" (Whelehan, 2000: 5), that he was simply an 'aspirational invention' (Edwards, 2003: 144), that, ultimately, he "does not actually exist; he is an ideological construct" (Hondagneu-Sotelo and Messner, 1994: 206). Are chick texts then re-imagining this aspirational invention and purporting this same ideological construct, all the while recognising the irony of this? Or are they simply providing women with a fictitious version of what is 'impossible' to find in real life, a kind of consolation prize and a chance to escape? Or is something more significant at work? Rowena Chapman suggested a more 'sinister' understanding of the 'new man' image and the cultural dominance he upheld: 
Networking Knowledge: Journal of the MeCCSA Postgraduate Network, Vol. 4, No. 1 (2011)

Everything changes but stays the same. Men are still the standard of normality. Their acceptance of feminine qualities substantiates their personalities... men still write the rules... the new man is many things - a humanist ideal... a ruse to persuade those that called for change that it has already occurred. Another more sinister possibility is that he is patriarchal mutation, a redefinition of masculinity in men's favour, a reinforcement of the gender order, representing an expansion of the concept of legitimate masculinity, and thus an extension of its power over women.

(Chapman, 1988: 247)

This then leaves us with more questions than answers and certainly further study is needed to continue exploring these genres in order to fully consider the political and social implications of this persistent framing of the 'ideologically constructed' and 'non-existent' new man for contemporary women. 
Networking Knowledge: Journal of the MeCCSA Postgraduate Network, Vol. 4, No. 1 (2011)

\section{REFERENCES}

Abbott, Stacey and Jermyn, Deborah. eds. (2009) Falling in Love Again: Romantic Comedy in Contemporary Cinema. London: I.B. Taurus.

Beynon, John. (2002) Masculinities and Culture. Buckingham: Open University Press.

Bordo, Susan. (2001) The Male Body: A New Look at Men in Public and in Private. New York: Farrar, Straus \& Giroux Inc.

Bordo, Susan. (2003) Unbearable Weight: Feminism, Western Culture and the Body (Tenth Anniversary Edition). London: University of California Press.

Brunner, Laura A.K. (2010) 'How Big is Big Enough?', Feminist Media Studies, 10:1, pp.8798.

Chapman, Rowena. (1988) 'The Great Pretender: Variations on the New Man Theme' in Chapman, Rowena and Rutherford, Jonathan, eds., Male Order: Unwrapping Masculinity. London: Lawrence and Wishart, pp.225-248.

Edwards, Tim. (1997) Men in the Mirror: Men's Fashion, Masculinity and Consumer Society. London: Cassell.

Edwards, Tim. (2003) 'Sex, Booze and Fags: Masculinity, Style and Men's Magazines' in Benwell, Bethan, ed., Masculinity and Men's Lifestyle Magazines. Oxford: Blackwell, pp.132146.

Edwards, Tim. (2006) Cultures of Masculinity. Abingdon: Routledge.

Ferriss, Suzanne and Young, Mallory. eds. (2006) Chick Lit: The New Women's Fiction. Abingdon: Routledge. 
Networking Knowledge: Journal of the MeCCSA Postgraduate Network, Vol. 4, No. 1 (2011)

Ferriss, Suzanne and Young, Mallory. eds. (2008) Chick Flicks: Contemporary Women at the Movies. Abingdon: Routledge.

Fest, Kerstin. (2009) 'Angels in the House or Girl Power: Working Women in Nineteenth Century Novels and Contemporary Chick Lit', Women's Studies, 38:1, pp.43-62.

Genz, Stéphanie and Brabon, Benjamin A. (2009) Postfeminism: Cultural Texts and Theories. Edinburgh: Edinburgh University Press.

Gill, Rosalind. (2003) 'Power and the Production of Subjects: A Genealogy of the New Man and the New Lad' in Benwell, Bethan, ed., Masculinity and Men's Lifestyle Magazines. Oxford: Blackwell, pp.34-56.

Gill, Rosalind, Henwood, Karen and McLean, Carl. (2005) 'Body Projects and the Regulation of Normative Masculinity', Body \& Society, 11:1, pp.37-62.

Gill, Rosalind and Herdieckerhoff, Elena. (2006) 'Rewriting the Romance: New Femininities in Chick Lit?', Feminist Media Studies, 6:4, pp.487-504.

Gill, Rosalind. (2007) Gender and the Media. Cambridge: Polity.

Harzewski, Stephanie. (2006) 'Tradition and Displacement in the New Novel of Manners' in Ferriss, Suzanne and Young, Mallory, eds, Chick Lit: The New Women's Fiction. Abingdon: Routledge, pp.29-46.

Harzewski, Stephanie. (2011) Chick Lit and Postfeminism. Charlottesville and London: University of Virginia Press.

Hewitt, Heather. (2006) 'You Are Not Alone: The Personal, the Political, and the 'New' Mommy Lit' in Ferriss, Suzanne and Young, Mallory, eds., Chick Lit: The New Women's 
Networking Knowledge: Journal of the MeCCSA Postgraduate Network, Vol. 4, No. 1 (2011)

Fiction. Abingdon: Routledge, pp.119-140.

Hollows, Joanne. (2006) 'Can I go Home Yet? Feminism, Post-Feminism and Domesticity' in Hollows, Joanne and Moseley, Rachel, eds., Feminism in Popular Culture. Oxford: Berg, pp.97-118.

Gillis, Stacey and Hollows, Joanne. eds. (2009) Feminism, Domesticity and Popular Culture. Abingdon: Routledge.

Hondagneu-Sotelo, Pierrette and Messner, Michael A. (1994) 'Gender Displays and Men's Power' in Brod, Harry and Kaufman, Michael, eds., Theorizing Masculinities. London: Sage pp.200-218.

Kaufman, Michael. (1994) 'Men, Feminism and Men's Contradictory Experiences of Power' in Brod, Harry and Kaufman, Michael, eds., Theorizing Masculinities. London: Sage, pp.142163.

Kimmel, Michael S. (1994) 'Masculinity as Homophobia: Fear, Shame, and Silence in the Constructions of Gender Identity' in Brod, Harry and Kaufman, Michael, eds., Theorizing Masculinities. London: Sage, pp.119-141.

Mabry, A. Rochelle. (2006) 'About A Girl: Female Subjectivity and Sexuality in Contemporary 'Chick' Culture' in Ferriss, Suzanne and Young, Mallory, eds., Chick Lit: The New Women's Fiction. Abingdon: Routledge, pp.191-206.

Modleski, Tania. (1982) Loving With A Vengeance: Mass-Produced Fantasies for Women. London: Routledge.

Mort, Frank. (1996) Cultures of Consumption: Masculinities and Social Space in Late Twentieth-Century Britain. London: Routledge. 
Networking Knowledge: Journal of the MeCCSA Postgraduate Network, Vol. 4, No. 1 (2011)

Mortimer, Claire. (2010) Romantic Comedy. London: Routledge.

Moseley, Rachel and Read, Jacinda. (2002) 'Having It Ally': Popular Television (Post-) Feminism', Feminist Media Studies, 2:2, pp.231-249.

Mulvey, Laura. (1975) 'Visual Pleasure and Narrative Cinema', Screen 16:3, pp. 6-18

Negra, Diane. (2008) 'Structural Integrity, Historical Reversion, and the Post-9/11 Chick Flick', Feminist Media Studies, 8:1, pp.51-68.

Negra, Diane. (2009) What a Girl Wants? Fantasising the Reclamation of Self in Postfeminism. Abingdon: Routledge.

Nixon, Sean. (2001) 'Resignifying Masculinity: From 'New Man' to 'New Lad' in Morley, David, and Robins, Kevin, eds., British Cultural Studies: Geography, Nationality and Identity. Oxford: Oxford University Press, pp. 373-386.

Rubinfeld, Mark D. (2001) Bound To Bond: Gender, Genre, and the Hollywood Romantic Comedy. Connecticut: Praeger.

Rüll, Lisa M. (2008) 'A Soundtrack for our Lives: Chick Flick Music' in Ferriss, Suzanne and Young, Mallory, eds, Chick Flicks: Contemporary Women at the Movies. Abingdon: Routledge, pp.79-91.

Rutherford, Jonathan. (1988) 'Who's That Man?' in Chapman, Rowena and Rutherford, Jonathan, eds., Male Order: Unwrapping Masculinity. London: Lawrence and Wishart, pp.2167.

Segal, Lynne. (2007) Slow Motion: Changing Masculinities, Changing Men (Third Edition). Basingstoke: Palgrave Macmillan. 
Networking Knowledge: Journal of the MeCCSA Postgraduate Network, Vol. 4, No. 1 (2011)

Smith, Caroline J. (2008) Cosmopolitan Culture and Consumerism in Chick Lit. Abingdon: Routledge.

Tasker, Yvonne. (1993) Spectacular Bodies: Gender, Genre and the Action Cinema. London: Routledge.

Wells, Juliette. (2006) 'Mothers of Chick Lit? Women Writers, Readers, and Literary History' in Ferriss, Suzanne and Young, Mallory, eds, Chick Lit: The New Women's Fiction. Abingdon: Routledge, pp.47-70.

Whelehan, Imelda. (2000) Overloaded: Popular Culture and the Future of Feminism. London: Namara Group.

\section{BIBLIOGRAPHY OF CHICK TEXTS}

\section{LITERATURE}

Ashley, Trisha (2010) Twelve Days of Christmas. London: Avon.

Austen, Jane. (2006) Pride and Prejudice. London: Headline Review.

Bagshawe, Louise. (2004) Monday's Child. London: Headline.

Bagshawe, Louise. (2005) Tuesday's Child. London: Headline.

Burgess, Gemma. (2009) The Dating Detox. London: Avon.

Burgess, Gemma. (2011) A Girl Like You. London: Avon. 
Networking Knowledge: Journal of the MeCCSA Postgraduate Network, Vol. 4, No. 1 (2011)

Colgan, Jenny. (2010) The Good, The Bad and The Dumped. London: Sphere.

Costello, Jane. (2008) Bridesmaids. London: Pocket.

Costello, Jane. (2009) The Nearly-Weds. London: Pocket.

Costello, Jane. (2010) My Single Friend. London: Pocket.

Costello, Jane. (2011) Girl On The Run. London: Simon \& Schuster.

Dickinson, Miranda. (2009) Fairytale of New York. London: Avon.

Dickinson, Miranda. (2010) Welcome To My World. London: Avon.

Fielding, Helen. (1997) Bridget Jones’s Diary. London: Picador.

Fielding, Helen. (1999) Bridget Jones' Diary: The Edge of Reason. London: Picador.

Green, Jane. (1999) Mr Maybe. London: Penguin.

Green, Jane. (2002) Babyville. London: Penguin.

Green, Jane. (2005) The Other Woman. London: Penguin.

Green, Jane. (2006) Life Swap. London: Penguin.

Harrison, Kate. (2008) The Secret Shopper's Revenge. London: Orion.

Harrison, Kate. (2010) The Secret Shopper Unwrapped. London: Orion. 
Networking Knowledge: Journal of the MeCCSA Postgraduate Network, Vol. 4, No. 1 (2011)

Jewell, Lisa. (2007) 31 Dream Street. London: Penguin.

Jones, Belinda. (2007) The Love Academy. London: Arrow.

Jones, Belinda. (2008) Out of the Blue. London: Arrow.

Jones, Belinda. (2010) Living La Vida Loca. London: Hodder \& Stoughton.

Jones, Christina. (1997) Going The Distance. London: Orion.

Kelk, Lindsey. (2009) I Heart New York. London: Harper.

Kelk, Lindsey. (2010a) I Heart Hollywood. London: Harper.

Kelk, Lindsey. (2010b) I Heart Paris. London: Harper.

Kinsella, Sophie. (2000) The Secret Dreamworld of a Shopaholic. London: Black Swan.

Kinsella, Sophie. (2001) Shopaholic Abroad. London: Black Swan.

Kinsella, Sophie. (2002) Shopaholic Ties the Knot. London: Black Swan.

Kinsella, Sophie. (2003) Can You Keep a Secret? London: Black Swan.

Kinsella, Sophie. (2004) Shopaholic and Sister. London: Bantam.

Kinsella, Sophie. (2006) The Undomestic Goddess. London: Black Swan.

Kinsella, Sophie. (2007) Shopaholic \& Baby. London: Bantam. 
Networking Knowledge: Journal of the MeCCSA Postgraduate Network, Vol. 4, No. 1 (2011)

Kinsella, Sophie. (2008) Remember Me. London: Black Swan.

Kinsella, Sophie. (2010) Mini Shopaholic. London: Bantam.

McNamara, Ali. (2010) From Notting Hill with Love... Actually. London: Sphere.

Nathan, Melissa. (2000) Acting Up. London: Arrow.

Nathan, Melissa. (2001) Persuading Annie. London: Arrow.

Nathan, Melissa. (2003) The Nanny. London: Arrow.

Nathan, Melissa. (2004) The Waitress. London: Arrow.

Nathan, Melissa. (2006) The Learning Curve. London: Arrow.

Neill, Fiona. (2008) The Secret Life of a Slummy Mummy. London: Random House.

Potter, Alexandra. (2006) Be Careful What You Wish For. London: Hodder \& Stoughton.

Potter, Alexandra. (2007) Me and Mr Darcy. London: Hodder \& Stoughton.

Potter, Alexandra. (2009) Who's That Girl? London: Hodder \& Stoughton.

Potter, Alexandra. (2010) Do You Come Here Often? London: Hodder \& Stoughton.

Potter, Alexandra. (2011) Calling Romeo. London: Hodder \& Stoughton.

Toon, Paige. (2007) Lucy in the Sky. London: Pocket. 
Networking Knowledge: Journal of the MeCCSA Postgraduate Network, Vol. 4, No. 1 (2011)

Toon, Paige. (2008) Johnny Be Good. London: Pocket.

Toon, Paige. (2009) Chasing Daisy. London: Pocket.

Toon, Paige. (2010) Pictures of Lily. London: Pocket.

\section{FILM}

13 Going on 30 (2004) Dir. Gary Winick. Sony Pictures.

27 Dresses (2008) Dir. Anne Fletcher. Twentieth Century Fox.

A Lot Like Love (2005) Dir. Nigel Coles. Walt Disney Pictures.

Bridget Jones'Diary (2004) Dir. Sharon Maguire. Universal Pictures.

Bridget Jones'Diary: The Edge of Reason. (2006) Dir. Beeban Kidron. Universal Pictures.

Definitely Maybe (2008) Dir. Adam Brooks. Universal Pictures.

Enchanted (2007) Dir. Kevin Lima. Walt Disney Studios.

Failure to Launch (2006) Dir. Tom Dey. Paramount.

He's Just Not That Into You (2009) Dir. Ken Kwapis. Entertainment in Video.

How to Lose a Guy in Ten Days (2003) Dir. Donald Petrie. Paramount. 
Networking Knowledge: Journal of the MeCCSA Postgraduate Network, Vol. 4, No. 1 (2011)

Just Like Heaven (2006) Dir. Mark Waters. Dreamworks.

Letters to Juliet (2010) Dir. Gary Winick. E1 Entertainment.

Love Actually (2003) Dir. Richard Curtis. Universal Pictures.

Maid In Manhattan (2003) Dir. Wayne Wang. Sony Pictures.

Music and Lyrics (2007) Dir. Marc Lawrence. Warner Home Video.

New In Town (2009) Dir. Jonas Elmer. Entertainment in Video.

No Reservations (2007) Dir. Scott Hicks. Warner.

Notting Hill (1999) Dir. Roger Michell. Universal Pictures.

Sex and the City (2008) Dir. Michael Patrick King. Entertainment in Video.

Sweet Home Alabama (2002) Dir. Andy Tennant. Walt Disney Studios.

The Devil Wears Prada (2006) Dir. David Frankel. Twentieth Century Fox Home Entertainment.

The Family Stone (2005) Dir. Bezucha Thomas. Twentieth Century Fox Home Entertainment.

The Holiday (2007) Dir. Nancy Meyers. Universal Pictures.

The Proposal (2009) Dir. Anne Fletcher. Walt Disney Studios. 
Networking Knowledge: Journal of the MeCCSA Postgraduate Network, Vol. 4, No. 1 (2011)

The Runaway Bride (1999) Dir. Garry Marshall. Touchstone Home Video.

The Wedding Date (2005) Dir. Claire Kilner. Entertainment in Video.

Two Weeks Notice (2002) Dir. Marc Lawrence. Warner Home Video.

Valentine’s Day (2010) Dir. Garry Marshall. Warner Home Video.

What Happens in Vegas (2008) Dir. Tom Vaughan. Twentieth Century Fox Home Entertainment.

Wimbledon (2004) Dir. Richard Loncraine. Universal.

You've Got Mail (1999) Dir. Nora Ephron. Warner Home Video.

\section{ENDNOTES}


I am discussing chick texts aimed at adult women. There are a number of similar texts aimed at teens or even 'tweens' and these tend not to centralise the romance to the same extent, more often emphasising friendship.

ii

The section subheading 'what a handsome fine looking gentleman he is' is a phrase used to describe Jude Law by 'DreamKitty' on his 'page' on the IMDB website. Within one day the post had ten responses, all concurring that he is 'gorgeous', 'beautiful, elegant and sexy', 'handsome and sweet looking... but also hot and sexy'.

http://www.imdb.com/name/nm0000179/board/thread/179164789?p=1 (accessed 19/04/11)

iii

Whilst Enchanted might be classified as a children's film, it has enjoyed much popularity with women and follows many of the standard chick flick conventions, including its representation of masculinity. Therefore, along with Diane Negra (2009: 12-14) I feel it is appropriate to include it in discussion here.

iv

This quote is from the television series of Sex and the City, season 3 episode 3 "Attack of the Five Foot Ten Woman".

Mummy-lit developed in the early part of the 2000s, a sub-genre of chick lit. Here heroines have settled down with children and the story focuses more on their coping strategies and life choices. See Hewitt (2006) for further explanation. 